\title{
Kepastian Hukum Terhadap Perlindungan Karya Cipta Tari Jaipongan Di Wilayah Jawa Barat
}

\author{
Sulistijono \\ Fakultas Industri Kreatif Universitas Telkom, Bandung, Indonesia \\ E-mail: listijo@telkomuniversity.ac.id
}

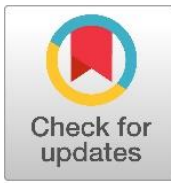

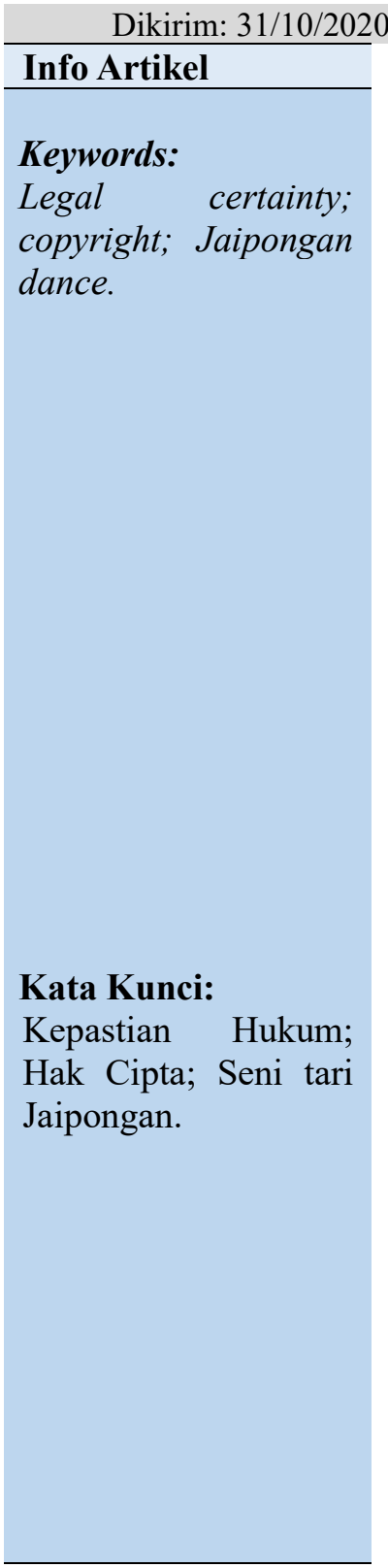

\begin{tabular}{ll} 
Direvisi: $21 / 11 / 2020$ & Dipublikasi: $25 / 12 / 2020$ \\
\hline Abstract & \\
The diversity possessed by the Indonesian nation starts from its various
\end{tabular} ethnicities, languages and cultures, Of course, this is inseparable from the participation of the community in developing the natural wealth owned by Indonesia, one of Indonesia's cultural wealth is the culture of dance in the West Java region, namely the jaipongan dance. Dance is a branch of the performing arts that has legal protection by copyright. The research method uses descriptive analytical research type, which is a study that describes or describes something that has happened or is currently taking place in a certain place and at a certain time, describing or describing the problems that have occurred.The analysis of the authors in this study, that the form of protection of Jaipongan dance creations in West Java is still limited to regulation because economic rights have not been realized properly so that legal certainty is not realized. The conclusion is to obtain legal certainty regarding the economic rights obtained from his works in the form of royalties, a special collective management agency for dance can be formed and the need for recording requirements procedures related to various dances that can be recorded.

\begin{tabular}{l}
\hline Abstrak \\
Keanekargaman yang dimiliki oleh Bangsa Indonesia mulai dari suku, \\
bahasa dan budaya yang beraneka ragam, tentunya ini tidak terlepas dari \\
peran serta masyarakat dalam menumbuh kembangkan kekayaan alami \\
yang dimiliki oleh Indonesia, salah satu kekayaan budaya Indonesia \\
adalah budaya seni tari di wilayah Jawa Barat yaitu seni tari Jaipongan. \\
Seni tari adalah satu cabang dari seni pertunjukan yang mendapatkan \\
perlindungan hukum oleh hak cipta. Metode penelitian menggunakan \\
tipe penelitian diskriptif analitis, yaitu suatu penelitian yang \\
menggambarkan atau melukiskan tentang suatu hal yang sudah terjadi \\
atau yang sedang berlangsung pada tempat tertentu dan pada saat \\
tertentu, menggambarkan atau melukiskan tentang masalah-masalah \\
yang terjadi. Analisa penulis dalam penelitian ini, bahwa bentuk \\
perlindungan terhadap karya cipta Tari Jaipongan di Jawa barat masih \\
sebatas pengaturan karena hak ekonomi belum terealisasi dengan baik \\
sehingga kepastian hukum tidak terwujud. Kesimpulan untuk
\end{tabular}


DOI:

$10.47268 /$ sasi.v26i4.428 memperoleh kepastian hukum terkait hak ekonomi yang diperoleh atas karya ciptanya dalam bentuk royalty, maka dapat membentuk Lembaga manajemen Kolektif khusus seni tari dan perlunya prosedur persyaratan pencatatan terkait dengan ragam tari yang dapat dicatatkan.

\section{A. PENDAHULUAN}

Suatu Kekayaan Intelektual (KI) merupakan hasil olah pikir intelektual manusia dari berbagi etnik, suku bangsa dan budaya berperan strategis dalam mendukung pembangunan bangsa ${ }^{1}$. Selain itu Hak kekayaan intelektual adalah hak yang timbul dari hasil pemikiran yang menghasilkan suatu produk yang berguna untuk orang lain. ${ }^{2}$ Sifat dari Hak Kekayaan Intelektual adalah hak kebendaan, yaitu hak atas sesuatu benda yang bersumber dari hasil kerja otak atau hasil kerja rasio, dimana hasil kerja tersebut dirumuskan sebagai intelektualitas, sehingga ketika sesuatu tercipta berdasarkan hasil kerja otak maka dirumuskan sebagai Hak Kekayaan Intelektual. ${ }^{3}$

Secara normatif, Hak Kekayaan Intelektual (HKI) adalah "product of mind" atau oleh World Intellectual Property Organization atau WIPO disebut "creation of the mind" yang berarti suatu karya manusia yang lahir dengan curahan tenaga, karsa, cipta, waktu ekonomi. Oleh karena itu, setiap karya intelektual patut diakui, dihargai dan dilindungi baik secara moral dan etika maupun dibangun dari konsep moral dan etika, sedangkan perlindungannya difasilitasi dengan instrument hukum Hak Cipta ${ }^{4}$.

Hak cipta itu sendiri sebagaimana diatur pada pasal 1 angka (1) Undang-Undang Nomor 28 Tahun 2014 tentang Hak Cipta adalah. "Hak ekslusif pencipta yang timbul secara otomatis berdasarkan prinsip deklaratif setelah suatu ciptaan diwujudkan dalam bentuk nyata tanpa mengurangi pembatasan sesuai dengan ketentuan peraturan perundangundangan".

Ciptaan atau karya-karya anak bangsa di Indonesia sangat bermanfaat bagi masyarakat baik secara ekonomi, kesehatan maupun kultur. Ciptaan dibuat oleh pencipta dalam hal ini adalah seseorang atau beberapa yang secara sendiri-sendiri atau bersama-sama menghasilkan suatu ciptaan ${ }^{6}$. Keanekargaman yang dimiliki oleh Bangsa Indonesia mulai dari suku, bahasa dan budaya yang beraneka ragam, tentunya ini tidak terlepas dari peran serta masyarakat dalam menumbuh kembangkan kekayaan alami yang dimiliki oleh Indonesia, salah satu kekayaan budaya Indonesia adalah seni.

Seni terdiri dari bermacam-macam jenis dan salah satunya adalah seni tari, dimana di era revolusi industry $4.0 \mathrm{ini}$, seni tari masih menjadi bagian yang terseksi untuk di bicarakan, seni tari melangkah maju dan berkembang sejalan dengan kehidupan manusia. Dimana manusia masih mampu bergerak, maka tari akan tercipta dan berkembang. Manusia menciptakan tari sesuai dengan ungkapan hidup dan juga merupakan rangkuman gerak yang

1 Badan Penelitian dan Pemnembangan HAM Kemhan RI. (2013) Perlindungan Kekayaan Intelektual atas Pengetahuan Tradisional dan ekspresi budaya Tradisional masyarakat adat. Bandung: Alumni, h.1

2 Raharjo, R. S. (2018). Perlindungan Hukum terhadap Pencipta atas Pencatatan Suatu Ciptaan yang Sama. Lentera Hukum, 5 (3), h. 464.

3 Labetubun, Muchtar Anshary Hamid. (2018). Aspek Hukum Hak Cipta Terhadap Buku Elektronik (EBook) Sebagai Karya Kekayaan Intelektual, SASI, 24 (2): 138-149. h. 138.

4 Napitupulu, D. P. T \& Muaz Zul. (2013). Perlindungan Hak Cipta Kesenian Daerah Tari Tor-Tor dan Gondang Sembilan. Mercatoria 6 (1), h. 86.

5 Pasal (1) angka 1 Undang-Undang Nomor 28 Tahun 2014 tentang Hak Cipta.

6 Khotimah, V. (2018). Keabsahan Kepemilikan Hak Cipta Koreografi di Lingkungan Dosen Institut Seni Indonesia Yogyakarta, JIPRO, 1 (1). h. 233. 
bersumber dari alam se-keliling ${ }^{7}$, selain karyanya yang begitu indah dengan gerakan yang dinamis dan terstruktur, seni tari ini mewakili keanekaragaman budaya di Indonesia dari Sabang sampai Merauke, salah satu seni tari itu adalah seni tari Jaipong yang berasal dari Jawa Barat.

Seni Tari Jaipong merupakan bagian dari adat budaya kesenian tari Jawa Barat. Jaipongan merupakan hasil pengalaman estetik para penciptanya yang diungkapkan dalam berbagai bentuk koreografi dan unsur pendukung lainnya. Jaipongan pada saat ini menjadi icon bagi masyarakat Jawa Barat yang secara tidak langsung telah mempengaruhi bentuk kesenian asalnya. Kesenian Ketuk Tilu dan kesenian Bajidoran sebagai bahan dasar dari kesenian Jaipongan secara perlahan mulai terpengaruh dengan idiom-idiom kesenian Jaipongan, sebagai bentuk akulturasi kesenian masa lampau dengan yang baru sehingga menghasilkan idiom-idiom baru tanpa memengaruhi bagian-bagian tertentu dalam aturan, norma dan nilai keseniannya. Gugum Gumbira dapat memberikan kekuatan spirit terhadap perkembangan tari Jaipongan yang tidak lepas dari kebiasaan dan pola-pola kehidupan karya sebelumnya ${ }^{8}$.

Pada zaman yang penuh dengan perkembangan ilmu pengetahuan dan tehnologi Seni Tari Jaipongan telah mengalami transformasi yang luar biasa, kreativitas seni yang indah menjadikan tari jaipongan telah dikenal luas keseluruh pelosok Indonesia bahkan sampai kemancanegara, pelestariannya kian gencar dan para seniman tari di Jawa Barat banyak menghasilkan karya-karya yang gemilang. Seni tari adalah satu cabang dari seni pertunjukan yang mendapatkan perlindungan hukum oleh hak cipta. Hal ini dapat dilihat pengaturannya di dalam Pasal 40 ayat (1) huruf e Undang-Undang Hak Cipta Nomor 28 Tahun 2014.

Perlindungan Hak Cipta khususnya terhadap karya cipta tari Jaipongan menjadi masalah serius, dimana di dalam kenyataannya dewasa ini yaitu adanya karya cipta tari Jaipongan yang diubah bentuk gerak tarinya, adanya pembajakan karya tari oleh sanggar-sanggar tari lainnya ${ }^{9}$ dan yang tidak kalah sedihnya adanya kekayaan intelektual berupa karya cipta tari milik Indonesia yang diklaim oleh negara lain, seperti yang pernah dilakukan oleh Malaysia mengklaim beberapa kekayaan budaya Indonesia, diantaranya seni batik, seni tari, seni musik dan lain sebagainya, hal inilah yang menjadi ancaman bagi Pemerintah Indonesia untuk segera menentukan sikap yang tegas dan membuat suatu kebijakan guna melindungi dan memberikan kepastian hukum terhadap berbagai karya cipta seni budaya yang sangat berpotensi untuk mendapatkan hak moral dan hak ekonomi dimasa sekarang maupun dimasa yang akan datang.

Berdasarkan latar belakang tersebut yang telah dijelaskan diatas menjadi topik yang menarik untuk dibahas dan menjadi tema sentral dalam jurnal ini yaitu Bagaimana Kepastian Hukum Terhadap Perlindungan Karya Cipta Tari Jaipongan Di Wilayah Jawa Barat dan bagaimana suatu karya cipta tari khususnya tari Jaipongan dapat di catatkan di Ditjen Kekayaan Intelektual?.

\section{B. METODE PENELITIAN}

Tipe penelitian yang digunakan peneliti adalah diskriptif analitis, yaitu suatu penelitian yang menggambarkan atau melukiskan tentang suatu hal yang sudah terjadi atau yang

${ }^{7}$ Khutniah, N. \& Iryanti, V. E. (2012). Upaya Mempertahankan Eksistensi Tari Kridha Jati di Sanggar Hayu Budaya Keluarahan Pengkol Jepara. Jurnal Seni Tari Unnes, h. 10.

${ }^{8}$ Nuriawati, R \& Nalan, A. S. (2018). Kreativitas Gondo Dalam Tari Jaipongan. Makalangan, 5 (2), h. 30 .

9 Wawancara dengan Juwita, Pemilik Sanggar Tari Sekar Budaya Nusantara, Bogor, dilaksanakan pada tanggal 17 Agustus 2020 via whatsaff.

476 |S A S I Vo1. 26 No.4, Oktober - Desember 2020 
sedang berlangsung pada tempat tertentu dan pada saat tertentu, menggambarkan atau melukiskan tentang masalah-masalah yang terjadi, terkait kepastian hukum terhadap Perlindungan Karya Cipta Tari Jaipongan Di Wilayah Jawa Barat. Dengan jenis penelitian dengan menggunakan penelitian Yuridis normati ${ }^{10}$ yaitu hukum dikonsepsikan sebagai norma, kaidah, asas atau pun dogma. Adapun pendekatan masalah yang dipergunakan peneliti dalam membahas masalah yang berkenaan dengan terkait kepastian hukum Terhadap Perlindungan Karya Cipta Tari Jaipongan Di Wilayah Jawa Barat adalah pendekatan yuridis normatif. Menurut Soerjono Soekanto penelitian Yuridis hukum Normatif tidak diperlukan penyusunan atau perumusan hipotesa. Mungkin suatu hipotesa kerja diperlukan, yang biasanya mencakup sistematika kerja dalam proses penelitian. ${ }^{11}$ Pada Penelitian hukum normatif yang sepenuhnya mempergunakan data sekunder maka penyusunan kerangka teoritis yang bersifat tentatif dapat ditinggalkan. ${ }^{12}$.

\section{PEMBAHASAN}

\section{Kepastian Hukum Terhadap Perlindungan Karya Cipta Tari Jaipongan Di Wilayah Jawab Barat}

\section{a. Gambaran Umum Tari Jaipong Jawa Barat Tari Jaipongan}

Di masa silam, tari-tarian rakyat yang dimiliki masyarakat Sunda sangat banyak jumlahnya dan bisa diperkirakan hidup marak, karena semuanya selalu dikaitkan dengan ritual. Dari sekian banyak tari rakyat yang berkembang di masyarakat Indonesia, salah satunya yaitu tari Jaipongan yang berasal dari Jawa Barat. Awal kemunculan tari Jaipongan merupakan kolaborasi dari gerakan Ketuk Tilu, tari Ronggeng dan beberapa gerak Pencak Silat yang pada saat itu disukai oleh kalangan masyarakat sebagai sarana pergaulan. Jaipong awalnya dikenalkan oleh Suanda lewat tepak kendangnya dalam mengiringi penari di daerah Karawang, yang kemudian oleh Gugum Gumbira dikolaborasikan dengan menyatukan tepak kendang Jaipong dan koreografi yang diciptakannya, maka dari situlah muncul istilah ketuk tilu kiwari sebelum berubah menjadi Jaipongan ${ }^{13}$.

Dalam wawancara dengan pemilik sanggar tari Sekar Budaya Nusantara mengatakan bahwa ${ }^{14}$ : "Seni tari jaipongan tidak hanya dapat ditarikan oleh penari wanita saja tetapi penari pria pun dapat melakukannya tergantung jenis tarian jaipongan yang akan ditampilkan, seni tari jaipongan identik dengan goyangan yang unik, ketu tilu jaipongan dipadu padankan dengan pencak silat ala sunda”.

Tarian jaipongan yang ditarikan selama ini telah mengalami berbagai bentuk/pola tarian dimulai dari kostum sampai dengan gerakan tariannya, tampilan kostum Jaipongan sejak awal kemunculannya hingga kini semakin bervariasi, sehingga memungkinkan terjadinya pergeseran dalam hal siluet kostumnya. ${ }^{15}$

Berikut salah satu contoh tari Jaipongan dengan kostum yang telah dimodifikasi modernisasi:

10 Soemitro, R. H. (2014), Metodologi Penelitian Hukum dan Jurimentri. Jakarta: Ghalia, h. 106.

11 Soekanto, S. (2014), Pengantar Penelitian Hukum. Jakarta: Universitas Indonesia-Press, h 53.

12 Ibid, hlm 52

13 Jumantri, M. C. \& Nugraheni, T. (2020), Pengkajian Gaya Busana Tari Jaipongan Karya Sang Maestro The Study of Jaipongan Dance Costume by The Maestro, Gondang, 4 (1), h. 10.

14 Wawancara dengan Ibu Juwita, Op Cit.

15 Marlianti, M., Saidi, A. I., Destiarmand, A. H. (2017). Pergeseran Bentuk Siluet Kostum tari Jaipongan, Panggung, 27 (1), h. 50. 


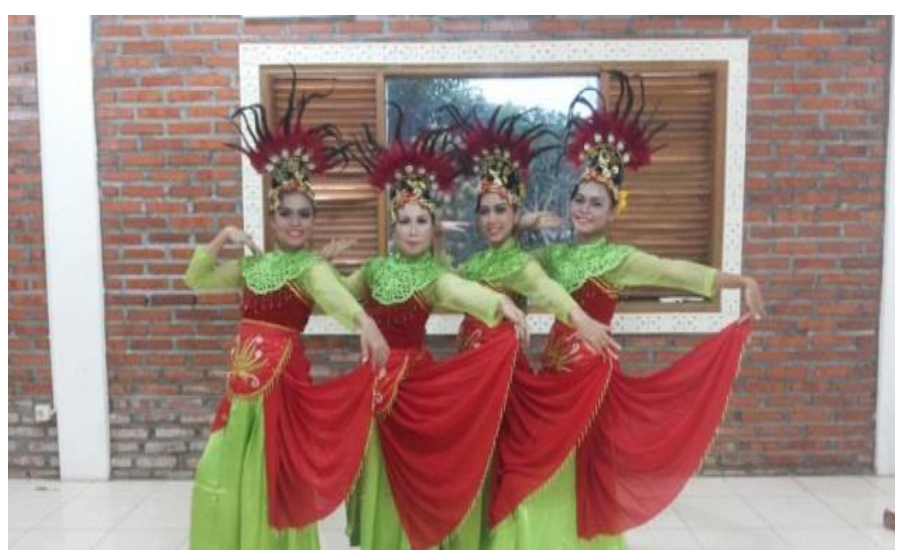

Gambar 1. Tari Jaipongan

\section{b. Perlindungan Karya Cipta Tari Jaipongan Di Wilayah Jawa Barat}

Karya cipta tari adalah ekspresi dari sebuah ide, bukan melindungi idenya, artinya yang dilindungi hak cipta adalah sudah dalam bentuk nyata sebagai suatu ciptaan, bukan masih merupakan gagasan. Ciptaan atau karya cipta yang mendapat perlindungan hak cipta atau sebagai obyek dari hak cipta adalah ciptaan yang merupakan hasil proses penciptaan atas inspirasi, gagasan atau ide berdasarkan kreatifitas pikiran, imajinasi, kecekatan, keterampilan atau keahlian pencipta dan dalam penuangannya harus memliki bentuk yang khas dan menunjukkan keaslian (orginal) ciptaan seseorang yang bersifat pribadi, dalam bentuk yang khas, artinya karya tersebut harus telah selesai diwujudkan, sehingga dapat dilihat, didengar atau dibaca. ${ }^{16}$

Di dalam pembahasan mengenai karya tari sebagai hak cipta yang dilindungi tentunya tidak lepas dari peristilahan pencipta dan ciptaan. Pencipta Tari dan ciptaan adalah dua hal yang tidak dapat dipisahkan. Keduanya saling menentukan dan saling membutuhkan. Pencipta Tari dalam keadaan tertentu dapat dikatakan sebagai manusia biasa yang memiliki kemampuan "luar biasa". Dalam kehidupan sehari-hari Pencipta Tari adalah bagian dari anggota masyarakat, ia harus berinteraksi dengan warga masyarakat lainnya, namun dalam hal tertentu terutama dalam hal berkesenian Pencipta Tari tergolong orang-orang yang memiliki bakat, kemampuan, dan ketrampilan ${ }^{17}$.

Penghargaan yang diberikan kepada Pencipta karya seni tari sesuai dengan Teori Perlindungan Hak Kekayaan Intelektual dari Robert M. Sherwood, ${ }^{18}$ yang mendasari perlunya perlindungan hak yaitu sebagaimana Tabel 1 berikut ini :

Tabel 1. Teori Perlindungan Hak Cipta

\begin{tabular}{ccc}
\hline No. & Jenis Teori & Keterangan \\
\hline 1 & Reward Theory & $\begin{array}{l}\text { berupa pengakuan terhadap karya intelektual yang telah } \\
\text { dihasilkan oleh seseorang sehingga kepada penemu/ }\end{array}$ \\
\hline
\end{tabular}

16 Rahmadi. (2010). Hukum Hak Atas Kekayaan Intelektual. Bandung: Alumni, h.121.

17 Juwita. (2016). Perlindungan Hukum terhadap Karya cipta tari di Indonesia. Desertasi. Universitas Hasanuddin, h. 144

18 Mahardhita, Y. \& Sukro, A. Y. (2018). Perlindungan hukum hak kekayaan intelektual melalui mekanisme “cross border measure”. Qistie 11 (1). h. 93-94 


\begin{tabular}{|c|c|c|}
\hline & & $\begin{array}{l}\text { pencipta atau pendesain harus diberikan penghargaan } \\
\text { sebagai imbangan atas upaya-upaya kreatif dalam } \\
\text { menemukan / menciptakan karya - karya intelektual } \\
\text { tersebut. }\end{array}$ \\
\hline 2 & Recovery Theory & $\begin{array}{l}\text { berupa pengembalian terhadap apa yang telah } \\
\text { dikeluarkan penemu/pencipta/pendesain yakni biaya, } \\
\text { waktu dan tenaga dalam proses menghasilkan suatu } \\
\text { karya. }\end{array}$ \\
\hline 3 & Incentive Theory & $\begin{array}{l}\text { berupa insentif yang diberikan kepada } \\
\text { penemu/pencipta/ pendesain untuk mengembangkan } \\
\text { kreatifitas dan mengupayakan tercapainya kegiatan - } \\
\text { kegiatan penelitian yang berguna. }\end{array}$ \\
\hline 4 & $\begin{array}{l}\text { Public Benefit } \\
\text { Theory }\end{array}$ & $\begin{array}{l}\text { berupa dasar pemberian perlindungan hak ataskekayaan } \\
\text { intelektual, yaitu untuk pengembangan ekonomi. }\end{array}$ \\
\hline 5 & Risk Theory & $\begin{array}{l}\text { berupa resiko yang terkandung pada setiap karya yang } \\
\text { dihasilkan. Suatu penelitian mengandung resiko yang } \\
\text { dapat memungkinkan orang lain menemukan karya } \\
\text { yang dihasilkan atau memperbaikinya dan resiko } \\
\text { mungkin timbul dari pergaulan secara illegal. }\end{array}$ \\
\hline 6 & $\begin{array}{l}\text { Economic } \\
\text { Grouth Stimulus } \\
\text { Theory }\end{array}$ & $\begin{array}{l}\text { Berupa perlindungan hak merupakan alat untuk } \\
\text { pembangunan ekonomi. }\end{array}$ \\
\hline
\end{tabular}

Berdasarkan Tabel 1 diatas maka relevan untuk diketahui sistem perlindungan Hak Cipta khususnya seni tari Jaipongan yaitu bentuk perlindungan hak cipta yang diberikan oleh negara melalui Undang-Undang Nomor 28 Tahun 2014 tentang Hak Cipta, menurut hukum hak cipta perlindungan hukum terhadap hasil karya seni tari diperoleh pencipta adalah secara otomatis artinya tanpa melalui proses pencatatan terlebih dahulu, begitu karya seni tari Jaipongan itu sudah terwujud dalam bentuk nyata melalui publikasi maka perlindungan hukum telah terjadi.

Jadi jelas bahwa Konsep tentang perlindungan hukum yang tercantum dalam undangundang Nomor 19 Tahun 2002 yang telah dirubah dengan undang-undang Nomor 28 tahun 2014, yaitu pasal 40 ayat (1) sampai ayat (3) yang menjelaskan tentang ciptaan yang dilindungi. Perlindungan hukum adalah suatu perlindungan yang timbul dan diberikan terhadap subyek hukum dalam bentuk perangkat hukum, bersifat preventif maupun yang bersifat refresif baik tertulis maupun tidak tertulis. Dengan kata lain perlindungan hukum sebagai suatu gambaran dari fungsi hukum itu sendiri, yaitu konsep dimana hukum dapat memberikan suatu keadilan, ketertiban, kepastian, kemanfaatan, kedamaian bagi segala kepentingan manusia yang ada di dalam masyarakat. ${ }^{19}$

Selain itu menurut Bernard Nainggolan. ${ }^{20}$ Konsep dasar perlindungan hak cipta adalah hanya melindungi ide yang sudah berwujud atau memiliki bentuk (psycal form) dan asli (original), dalam hal ini dijelaskan bahwa perlindungan hak cipta tidak diberikan pada ide atau gagasan, karena karya cipta harus memiliki bentuk yang khas, bersifat pribadi dan

19 Rahardja, D. M. (2015). Perlindungan Hukum Terhadap Pencipta Lagu Yang Belum Di Daftarkan Ke Direktorat Jendral Hak Kekayaan Intelektual. Skripsi. Universitas Brawijaya, h. 7

20 Nainggolan, B. (2011) Pemberdayaan Hukum Hak Cipta lagu dan music melalui fungsi Lembaga manajemen Kolektif. Bandung: Alumni, h. 36. 
menunjukan keaslian sebagai ciptaan yang lahir berrdasarkan kemampuan, kreativitas dan keahlian sehingga ciptaan itu dapat dilihat, dibaca dan didengar.

Beberapa alasan Hak cipta tari khususnya tari Jaipongan di Jawa Barat mendapatkan perlindungan Hukum, dijelaskan dalam tabel 1 dibawah ini, yaitu ${ }^{21}$ :

Tabel 2. Alasan Perlindungan Hukum terhadap Karya Cipta Tari Jaipongan

\begin{tabular}{ll}
\hline No. Hak yang diperoleh & \multicolumn{1}{c}{ Alasannya } \\
\hline 1. Hak Ilmiah & \\
& alasan yang paling mendasar bagi Hak Cipta tari \\
& Jaipongan adalah bahwa seseorang yang \\
& telah mencurahkan usahanya untuk menciptakan \\
& sesuatu mempunyai hak alamiah /dasar untuk \\
& memiliki dan mengontrol apa-apa yang telah \\
& telah diciptakaannya yaitu moral dan ekonomi \\
\hline
\end{tabular}

2. Perlindungan HKI atas alasan yang paling mendasar bagi Hak cipta tari Reputasi Jaipongan adalah memperoleh hak moral, dengan cara ini tentunya untuk mencegah pihak lain memanfaatkan karya cipta tari tersebut dan mencegah pihak lain mengakui karya yang bukan haknya

3. Mendorong dan alasan yang paling mendasar bagi hak cipta tari menghargai penemuan Jaipongan adalah untuk mendorong dan dan kreasi menghargai pencipta karya seni tari Jaipongan yang menjadi mata pencaharian untuk terus berkarya

Dari uraian dalam tabel tersebut pada hakikatnya maksud perlindungan hak ilmiah berupa hak moral dan ekonomi adalah untuk mencegah orang lain yang bukan pencipta untuk mengeksploitasi ciptaan tanpa izin pencipta. Dalam konteks Undang-Undang Nomor 28 Tahun 2014 tentang Hak Cipta pengeksploitasian ciptaan tidak lain adalah melakukan perbanyakan dan pengumuman ciptaan ${ }^{22}$.

Dengan melihat substansi penjelasan yang tercantum pada penjelasan dari Pasal 38 ayat (1) UU No. 28 Tahun 2014 tentang Hak Cipta, maka jelaslah bahwa keberadaan seni tari menjadi salah satu objek yang dilindungi berdasarkan hukum hak cipta di Indonesia. Keberadaan Seni tari mempunyai fungsi dan peranan yang sangat strategis dalam berbagai aktivitas budaya, pariwisata, sosial, dan kemasyarakatan, yaitu antara lain:

1) Sebagai sarana pendukung berbagai bentuk upacara adat, contohnya tari penyambutan Sunda, tari penyambutan Betawi, penyambutan tamu negara dan lain sebagainya.

21 Juwita, Op Cit, h. 147.

22 Ibid, h. 37 
2) Sebagai sarana hiburan bagi masyarakat melalui pertunjukan pertunjukan seperti tari Jaipongan.

Selain itu Ekspresi Budaya Tradisional yang dilindungi mencakup salah satu atau kombinasi bentuk ekspresi berikut ini:

1) verbal tekstual, baik lisan maupun tulisan, yang berbentuk prosa maupun puisi, dalam berbagai tema dan kandungan isi pesan, yang dapat berupa karya ssastra ataupun narasi informatif;

2) musik, mencakup antara lain: vokal, instrumental atau kombinasinya;

3) gerak, mencakup antara lain: tarian, beladiri, dan permainan;

4) teater, mencakup antara lain: pertunjukan wayang dan sandiwara rakyat;

5) seni rupa, baik dalam bentuk dua dimensi maupun tiga dimensi yang terbuat dari berbagai macam bahan seperti kulit, kayu, bambu, logam, batu, keramik, kertas, tekstil, dan lain-lain atau kombinasinya; dan upacara adat, yang juga mencakup pembuatan alat dan bahan.

Karya cipta tari sebagai Ekspresi Budaya Tradisional maka berdasarkan pada ragam tari, penulis mengidentifikasi perlindungan hukum terhadap jenis ciptaan tersebut sebagai terdapat dalam tabel 3 sebagai berikut :

Tabel 3. Jenis Ciptaan Karya Seni tari

\begin{tabular}{|c|c|c|}
\hline No. & Jenis Karya Tari & Keterangan \\
\hline 1 & $\begin{array}{l}\text { Karya Tari yang tidak } \\
\text { diketahui penciptanya }\end{array}$ & $\begin{array}{l}\text { Tari ini adalah Tari klasik kraton dan tari } \\
\text { kerakyatan. } \\
\text { Biasanya hidup dan berkembang di dalam } \\
\text { suatu lingkungan masyarakat tertentu yang } \\
\text { biasanya berpijak dari unsur - unsur budaya } \\
\text { masyarakat setempat, dan penciptanya tidak } \\
\text { diketahui, sudah menjadi warisan masyarakat } \\
\text { setempat yang diajarkan secara turun temurun } \\
\text { serta dilestarikan dan dikembangkan oleh } \\
\text { masyarakat setempat. Sehingga hak cipta } \\
\text { dipegang oleh Negara sebagaimana diatur pada } \\
\text { Pasal } 38 \text { angka (1) UU No. } 28 \text { tahun } 2014 \\
\text { tentang Hak Cipta. }\end{array}$ \\
\hline 2 & $\begin{array}{l}\text { Karya Tari yang } \\
\text { diketahui penciptanya }\end{array}$ & $\begin{array}{l}\text { Tari ini adalah Tari kreasi baru, tari } \\
\text { kontemporer dan tari modern. } \\
\text { Hidup dan berkembang di zaman modern } \\
\text { sekarang ini, biasanya merupakan tari yang } \\
\text { sudah tidak mengikuti pakemnya atau sudah } \\
\text { meninggalkan ketentuan yang menjadi aturan } \\
\text { baku dalam tari terdahulu. Tari ini merupakan } \\
\text { murni ide pemikiran dari seorang seniman tari } \\
\text { yang hendak mengekspresikan sesuatu lewat } \\
\text { bahasa gerak tubuh atas sesuatu yang ia lihat, } \\
\text { rasakan dan proses perenungan terhadap } \\
\text { sesuatu hal. Tidak dipungkiri bahwa tari kreasi } \\
\text { baru ini ternyata ada juga yang merupakan }\end{array}$ \\
\hline
\end{tabular}


hasil kreasi terhadap tari tradisional baik klasik maupun kerakyatan dan masih mengikuti pakemnya (aturan yang ada) namun dilakukan kreasi terhadap waktu, kostum dan iringan musiknya.

Berdasarkan tabel 3 terkait dengan jenis ciptaan seni tari yang terdiri dari Karya Tari yang tidak diketahui penciptanya dan Karya Tari yang diketahui penciptanya menunjukan bahwa budaya Indonesia khususnya seni tari tidak hanya tari yang bersifat tradisional saja tetapi bentuk-bentuk lainpun menjadi bagian dari perkembangan seni tari itu sendiri.

Selanjutnya dalam konteks ciptaan, perlindungan Hak Cipta diperlukan untuk mendorong apresiasi dan membangun sikap masyarakat untuk menghargai hak seseorang atas ciptaan yang dihasilkannya. Sikap apresiasi memang lebih menyentuh dimensi moral, Sedangkan sikap menghargai lebih bermuara pada aspek ekonomi. Perlindungan Hukum Hak Cipta diarahkan untuk memungkinkan penggunaan ciptaan berlangsung secara tertib dan memberi manfaat ekonomi pada Pencipta.

Adapun bentuk perlindungan Hukum terhadap Seni tari Jaipongan sebagaimana tabel 4, dijelaskan sebagai berikut:

Tabel 4. Bentuk Perlindungan Hukum Terhadap karya Cipta Tari Jaipongan

\begin{tabular}{|c|l|l|}
\hline No. & Bentuk Perlindungan & \multicolumn{1}{c|}{ Keterangan } \\
\hline 1 & Pemberian hak Moral & $\begin{array}{l}\text { a. Integrity Right } \\
\text { Merupakan hak untuk tetap dijaga keutuhan } \\
\text { suatu ciptaan, pengubahan suatu ciptaan } \\
\text { harus mendapat izin atau persetujuan } \\
\text { pencipta atau ahli warisnya. }\end{array}$ \\
b. Paternity Right \\
Iak untuk tetap dicantumkan nama si pencipta \\
dimanapun ciptaan itu berada.
\end{tabular}

Berdasarkan tabel tersebut diatas bahwa hak moral sebagaimana diatur oleh pada Pasal 5 Undang-undang No. 28 Tahun 2014 tentang Hak Cipta. Sedangkan Hak ekonomi sebagaimana diatur oleh pada Pasal 8 dan 9 Undang-Undang Nomor 28 Tahun 2014 tentang Hak Cipta, menjelaskan hak ekonomi pencipta atau pemegang Hak Cipta. 
Hak ekonomi suatu ciptaan tetap berada di tangan pencipta atau pemegang hak cipta selama pencipta atau pemegang hak cipta tidak mengalihkan seluruh hak ekonomi dari pencipta atau pemegang hak cipta tersebut kepada penerima pengalihan hak atas ciptaan. Hak ekonomi yang dialihkan pencipta atau pemegang hak cipta untuk seluruh atau sebagian tidak dapat dialihkan untuk kedua kalinya oleh pencipta atau pemegang hak cipta yang sama sebagaimana diatur pada pasal 17 ayat (2) UU No. 28 Tahun 2014 tentang Hak Cipta.

Hak ekonomi bersifat mengenal waktu yaitu batas masa untuk menikmati manfaat ekonomi pada ciptaan. Dengan kata lain, merupakan batasan masa penguasaan monopoli dan peluang melakukan eksploitasi ciptaan. Bila batas waktu berakhir kekuatan monopoli juga berakhir. Status ciptaan dengan demikian menjadi public domain. Ini berarti masyarakat bebas mengeksploitasi tanpa memerlukan lisensi. ${ }^{23}$

Berdasarkan pembahasan tersebut maka penulis menganalisa berkaitan dengan adanya hak moral dan hak ekonomi di dalam suatu karya cipta, dalam hal ini adalah karya cipta seni tari maka seorang seniman tari juga memerlukan hak - hak tersebut. Bila hal ini dikaitkan dengan sebuah profesi maka sudah barang tentu bahwa penghormatan dan penghargaan mutlak diperlukan.

Hak moral dan hak ekonomi dalam perkembangannya juga diperlukan untuk kelangsungan anak cucu keturunannya. Berkaitan dengan adanya hak moral, hak tersebut merupakan sebuah prestise atau rasa kebanggaan bagi seorang seniman tari dalam statusnya di masyarakat dan pada prinsipnya ia merasa senang dan bangga ketika karya ciptanya dihargai secara moral oleh orang lain, artinya bahwa jika karya ciptanya itu akan dipentaskan oleh orang lain hendaknya disebutkan siapa penciptanya, hal ini dilakukan dalam rangka menghargai karya orang lain. Dan jika di dalam UUHC 2014 disebutkan juga adanya hak ekonomi, itu adalah sebagai salah satu penghargaan seorang seniman tari dalam dimensi ekonominya hal itu tentunya akan membuat seniman tari lebih semangat lagi untuk selalu berkarya dan berkreasi dalam membuat suatu karya cipta tari khususnya tari Jaipongan.

\section{c. Kepastian Hukum terhadap karya cipta seni tari Jaipongan}

Kepastian Hukum merupakan keadaan yang pasti, hukum secara hakiki harus pasti dan adil yang merupakan pedoman perilaku yang adil karena pedoman tersebut harus menunjang suatu tatanan yang dinilai wajar dan karena sifatnyalah yang adil sehingga dapat dilaksanakan dengan pasti hukum dan fungsinya, selain itu kepastian dan keadilan bukanlah sekedar tuntutan moral, melainkan secara faktual mencirikan hukum. ${ }^{24}$ Suatu hukum yang tidak pasti dan tidak mau adil bukan sekedar hukum yang buruk melainkan bukan hukum sama sekali, kedua sifat itu termasuk paham hukum itu sendiri. Hukum adalah sekumpulan peraturan-peraturan atau kaidah-kaidah dalam suatu kehidupan bersama keseluruhan peraturan tentang tingkah laku yang berlaku dalam suatu kehidupan bersama, yang dapat dipaksakan pelaksanaannya dengan suatu sanksi, Kepastian hukum akan selalu dikaitkan dengan perlindungan terhadap sesuatu yang menjadi permasalahan dan sesuatu tersebut adalah perlindungan terhadap karya cipta seni tari.

Dalam prakteknya kepastian hukum terhadap perlindungan karya cipta seni tari khususnya seni tari Jaipongan belum dapat dikatakan berjalan dengan baik sebagaimana diatur dalam Undang-Undang Nomor 28 Tahun 2014 tentang Hak Cipta, karena masih terdapat pemahaman yang belum dapat di-implementasikan kepada seniman seni tari terkait

23 Soelistyo, H. (2011). Hak Cipta tanpa Hak Moral. Jakarta: Rajawali, h. 29.

24 Sudikno. (2010). Perkembangan teori dalam ilmu hukum, Jakarta: PT. Radja Grafindo, h. 25 
pasal 40 ayat 1e terkait ciptaan yang dilindungi salah satunya seni tari, salah satunya adalah hak ekonomi dan hak moral.

Teringkarinya hak ekonomi dan hak moral bagi seniman seni tari atas karyanya dapat mengikis motivasi para Pencipta dan pemilik Hak Terkait untuk berkreasi. Hilangnya motivasi seperti ini akan berdampak luas pada runtuhnya kreativitas makro bangsa Indonesia, seperti yang dirasakan pada salah satu Pelatih Tari Jaipongan, yang mengatakan bahwa: ${ }^{25}$

"Seniman tari menikmati hasil karyanya setelah karyanya tersebut dipertunjukkan dalam suatu pementasan dan kelanjutan tidak ada lagi, kecuali ada pertunjukan pertunjukan lainnya yang si pencipta tari tersebut mengikuti pertunjukan tersebut, sedang pemanfaatan terhadap karya cipta seni tari sering dilakukan oleh beberapa sanggar tari tanpa melalui perizinan terhadap penciptanya itu sendiri”.

Berdasarkan fakta tersebut bahwa sesungguhnya perlindungan seni tari di Pasal 40 ayat 1e jelas dikatakan bahwa ciptaan yang dilindungi salah satunya adalah seni tari namun kenyataannya perlindungan tersebut tidak memiliki kepastian hukum, dimana dalam penerapan hak ekonomi para seniman tari khususnya tari Jaipongan tidak memiliki wadah/lembaga manajemen kolektif yang menghimpun royalty bagi seniman tari, hak ekonomi diperoleh seketika pada saat diadakan pertunjukan akan karyanya, dengan tidak adanya lembaga manajemen kolektif bagi karya cipta seni tari tentunya akan selalu dimanfaatkan oleh orang yang tidak bertanggungjawab untuk memperoleh keuntungan melalui pertunjukan tari dengan memanfaatkan karya tari orang lain, hal ini tentunya berpengaruh kepada kehidupan para seniman tari khususnya tari Jaipongan, semakin tua seniman tari tersebut semakin tidak memiliki penghasilan. Sangat miris kedengarannya namun demikian yang dirasakan oleh para seniman tari, selain hak moral, penegakkan hukum terhadap pelaku yang memanfaatkan karya orang lain tanpa izin yang seringkali dilakukan tidaklah mendapatkan sanksi sehingga hal ini apabila dibiarkan terus menerus tidak akan menimbulkan efek jera.

Dengan demikian dapat dikatakan bahwa kepastian hukum perolehan atas hak cipta khususnya karya cipta seni tari belumlah berjalan dengan baik, padahal secara normatif telah termuat dalam Undang-Undang Nomor 28 Tahun 2014 tentang Hak Cipta, apabila dikaji maka begitu mudah dapat dilaksanakan, namun yang terjadi sebaliknya, masalah kepastian hukum dalam kaitan dengan pelaksanaan hukum, memang sama sekali tak dapat dilepaskan sama sekali dari prilaku manusia. Kepastian hukum bukan mengikuti prinsip "pencet tombol" (subsumsi otomat), melainkan sesuatu yang cukup rumit, yang banyak berkaitan dengan faktor diluar hukum itu sendiri, ${ }^{26}$ dan dalam praktek kita melihat ada undangundang sebagian besar dipatuhi dan ada undang-undang yang tidak dipatuhi. Sistem hukum jelas akan runtuh jika setiap orang tidak mematuhi undang-undang dan undang-undang itu akan kehilangan maknanya. Ketidakefektifan undang-undang cenderung mempengaruhi waktu sikap dan kuantitas ketidakpatuhan serta mempunyai efek nyata terhadap perilaku hukum, termasuk perilaku pelanggar hukum. Kondisi ini akan mempengaruhi penegakan hukum yang menjamin kepastian dan keadilan dalam masyarakat ${ }^{27}$ khususnya seniman tari Jaipongan.

25 Wawancara dengan Ibu Yenni, Pelatih Tari dari Sanggar Rengganis, dilaksanakan pada tanggal 1 September 2020

26 Alfons, M. (2019). Kepastian Hukum perolehan Hak Atas Kekayaan Intelektual. Jatiswara, 31 (2), h. 309

27 Ibid, hlm 309

484 | S A S I Vol. 26 No.4, Oktober - Desember 2020 


\section{Prosedur pencatatan Karya cipta tari khususnya tari Jaipongan di Ditjen Kekayaan Intelektual}

Pada dasarnya pencatatan terhadap karya cipta khususnya seni tari Jaipongan bukan merupakan suatu keharusan bagi pencipta atau pemegang hak cipta karena timbulnya perlindungan suatu ciptaan dimulai sejak ciptaan itu ada atau terwujud dan bukan karena pencatatan. Hal ini berarti suatu ciptaan baik yang tercatat maupun tidak tercatat tetap mendapatkan perlindungan hukum. Namun demikian untuk lebih meyakinkan bahwa karya cipta tari khususnya tari Jaipongan tertera dalam suatu dokumen melalui Instansi yang berkompeten dalam hal ini adalah Ditjen Kekayaan Intelektual Kementerian Hukum dan HAM, seniman atau pencipta tari khususnya tari Jaipongan mencatatkan karyanya tersebut baik secara Online maupun manual sebagaimana diatur dalam pasal 64 ayat 1 dan 2 UndangUndang Nomor 28 tahun 2014 tentang Hak Cipta yang menyatakan ${ }^{28}$ :

1) Menteri menyelenggarakan pencatatan dan Penghapusan Ciptaan dan produk Hak Terkait.

2) Pencatatan Ciptaan dan produk Hak Terkait sebagaimana dimaksud pada ayat (1) bukan merupakan syarat untuk mendapatkan Hak Cipta dan Hak Terkait.

Berkaitan dengan pencatatan sebuah karya cipta khususnya seni tari Jaipongan, penulis belum melihat atau mendengar persyaratan khusus untuk pencatatan sebuah karya cipta tari yaitu:

a) Dalam Undang-Undang Nomor 28 tahun 2014 tentang Hak Cipta tidak mensyaratkan khusus bagi karya cipta seni tari kategori Seni tari yang dapat dicatatkan karena dalam seni tari terdapat 3 (tiga) unsur ciptaan yaitu Gerak tari, Musik dan Kostum.

Dalam seni tari Jaipongan, kadangkala ada tarian yang sudah ada lagu atau musiknya seperti contohnya adalah Jaipongan Bajidor Kahot, Mojang Priangan, Kalakay Murag, Kembang Tanjung dan lain sebagainya, namun ada pula tari Jaipongan yang memiliki musik baku gerak dan kostum dalam satu kesatuan contohnya Tari Nyi Obor. Hal inilah yang menjadi polemik bagi seniman tari dengan tidak ada persyaratan yang jelas dalam kategori ciptaan yang akan dicatatkan. Dalam wawancara penulis dengan seorang pencipta tari Jaipongan mengatakan bahwa ${ }^{29}$ :

Saat ini di Bandung untuk membuat sebuah karya tari Jaipongan menggunakan musik yang telah ada dengan gerak yang ciptakan sendiri oleh pencipta tarinya, sehingga apabila suatu saat diketemukan lagu yang sama contohnya tari Jaipongan Bajidor Kahot, dengan gerak tarian yang berbeda maka pencipta tari sangat kesulitan untuk mengklaim tarian Bajidor Kahot tersebut, karena setiap pencipta tari Jaipongan cenderung menggunakan music Jaipongan yang telah ada, hal ini tentunya musik dan lagu masuk dalam kategori karya cipta musik yang diatur dalam pasal tersendiri dalam Undang-Undang hak Cipta.

b) Dalam Undang-Undang Nomor 28 tahun 2014 tentang Hak Cipta tidak mensyaratkan ragam tarian yang dapat dicatatkan sebagaimana tabel 4 berikut ini:

28 pasal 64 angka 1 dan 2 Undang-Undang Nomor 28 tahun 2014 tentang Hak Cipta

29 Wawancara dengan Deden Kus, Seniman tari bandung dari sanggar Den's tradisional dance, dilaksanakan pada tanggal 5 September 2020 
Tabel 5. Ragam Tari

\begin{tabular}{|c|c|c|c|c|c|c|}
\hline No. & Jenis Tari & Sifat Tari & Iringan Musik & $\begin{array}{l}\text { Durasi } \\
\text { waktu }\end{array}$ & Busana & Nama pencipta \\
\hline 1 & $\begin{array}{l}\text { Tari Klasik } \\
\text { Kraton }\end{array}$ & $\begin{array}{l}\text { Mistis, Sakral, } \\
\text { estetis tinggi, } \\
\text { Upacara Keraton }\end{array}$ & $\begin{array}{l}\text { Gamelan } \\
\text { langsung dan } \\
\text { musik tradisi }\end{array}$ & $\begin{array}{l}\text { Lebih dari } 1 \\
\text { jam }\end{array}$ & $\begin{array}{l}\text { Kostum tari terkesan } \\
\text { mewah }\end{array}$ & $\begin{array}{l}\text { Raja dan atau } \\
\text { Empu tari zaman } \\
\text { dahulu serta abdi } \\
\text { dalem }\end{array}$ \\
\hline 2 & $\begin{array}{l}\text { Tari } \\
\text { Kerakyatan }\end{array}$ & $\begin{array}{l}\text { Mistis, Upacara } \\
\text { Kerakyatan, } \\
\text { pergaulan } \\
\text { estetis dan } \\
\text { sederhana }\end{array}$ & $\begin{array}{l}\text { Gamelan } \\
\text { langsung dan } \\
\text { musik tradisi }\end{array}$ & $\begin{array}{l}\text { Lebih dari } 1 \\
\text { jam }\end{array}$ & $\begin{array}{l}\text { Kostum sederhana namun } \\
\text { tetap indah dan bernuansa } \\
\text { kedaerahan }\end{array}$ & $\begin{array}{l}\text { Tidak diketahui } \\
\text { siapa } \\
\text { penciptanya }\end{array}$ \\
\hline 3 & $\begin{array}{l}\text { Tari } \\
\text { Tradisional } \\
\text { kreasi baru }\end{array}$ & Estetis, Hiburan & $\begin{array}{l}\text { Gamelan } \\
\text { langsung dan } \\
\text { musik tradisi }\end{array}$ & $\begin{array}{lr}\text { Kurang dari } \\
15 & \text { menit } \\
\text { dan } & 10 \\
\text { menit } & \end{array}$ & $\begin{array}{l}\text { Kostum sederhana namun } \\
\text { tetap indah dengan } \\
\text { bernuansa khas dari daerah } \\
\text { yang ditarikan yang telah } \\
\text { di modifikasi }\end{array}$ & $\begin{array}{l}\text { Seniman Tari } \\
\text { atau koreografer }\end{array}$ \\
\hline 4 & $\begin{array}{l}\text { Tari } \\
\text { Kontem } \\
\text { porer }\end{array}$ & Estetis Hiburan & $\begin{array}{l}\text { Musik daerah } \\
\text { yang } \\
\text { diaransemen } \\
\text { modern }\end{array}$ & $\begin{array}{lr}\text { Kurang dari } \\
15 & \text { menit } \\
\text { dan } & 10 \\
\text { menit } & \end{array}$ & $\begin{array}{l}\text { Kostum perpaduan antara } \\
\text { kedaerahan dan modern } \\
\text { yang dipadupadankan } \\
\text { sesuai dengan judul tarian }\end{array}$ & $\begin{array}{l}\text { Seniman Tari } \\
\text { atau koreografer }\end{array}$ \\
\hline 5 & $\begin{array}{l}\text { Tari } \\
\text { Modern }\end{array}$ & Estetis Hiburan & $\begin{array}{l}\text { Musik modern } \\
\text { dan dari musik } \\
\text { yang sudah ada }\end{array}$ & $\begin{array}{l}\text { Kurang dari } \\
10 \text { menit }\end{array}$ & $\begin{array}{l}\text { Kostum dapat bernunasa } \\
\text { kedarahan dapat pula } \\
\text { bernuansa modern dan } \\
\text { elegant disesuaikan } \\
\text { dengan judul tariannya }\end{array}$ & $\begin{array}{l}\text { Seniman Tari } \\
\text { atau koreografer }\end{array}$ \\
\hline
\end{tabular}

Sumber : Hasil wawancara dengan beberapa seniman tari Bandung, 2020

Berkaitan dengan hal tersebut, maka masih banyaknya karya cipta tari Jaipongan yang tidak dicatatkan di Ditjen Kekayaan Intelektual, karena belum adanya informasi yang secara akurat terkait prosedur pencatatan hak cipta tari, namun demikian secara umum persyaratan pencatatan dapat dijelaskan pada tabel 6 sebagai berikut ${ }^{30}$ :

Tabel 6. persyaratan pencatatan

Dokumen yang harus dilengkapi

Contoh Ciptaan dengan ketentuan

1. Nama, kewarganegaraan dan 1. Buku dan Karya Tulis lainnya : 2 buah alamat pencipta. yang telah dijilid dengan edisi terbaik.

2. Nama, kewarganegaraan dan Apabila suatu buku berisi foto seseorang alamat pemegang hak cipta.

3. Judul ciptan. 4. Tanggal dan tempat diumumkan dari orang yang difoto atau ahli untuk pertama kali.

5. Uraian singkat Ciptaan. harus dilampirkan surat tidak keberatan warisnya.

30 Am Badar \& Partners (2020) https://ambadar.co.id/news/pendaftaran-hak-cipta-di-indonesia/ 
6. Surat Kuasa yang 2. Program komputer (Software) 2 buah ditandatangani diatas materai "6.000".

CD disertai buku petunjuk pengoperasian.

7. Surat Pengalihan Hak (dari pencipta kepada Pemegang Hak Cipta) ditandatangani diatas meterai "6000").

8. Surat Pernyataan (menyatakan ciptaan tersebut adalah asli).

9. NPWP Perusahaan.

10. Foto Copy KTP Pemohon dan Pencipta.

11. Akta Perusahaan.

12. Contoh Ciptaan.

13. Surat Kuasa yang ditandatangani diatas materai "6.000"

3. Alat Peraga : 1 buah disertai dengan uraian ciptaannya.

4. Lagu : 10 buah berupa notasi dan atau syair.

5. Drama : 2 buah naskah tertulis atau rekamannya.

6. Tari (koreografi) : 10 bh gambar atau 2 buah rekamannya.

7. Pewayangan : 2 buah naskah tertulis atau rekamannya.

8. Pantomim : 10 buah gambar atau 2 buah rekamannya.

9. Karya pertunjukan : 2 buah rekamannya.

14. Surat pengalihan hak (apabila nama Pencipta berbeda dengan nama Pemegang Hak Cipta) ditandatangani diatas materai "6.000").

15. Surat Pernyataan (menyatakan ciptaan tersebut adalah asli)

16. NPWP

17. Foto Kopi KTP

18. 5 Contoh ciptaan

10. Karya siaran : 2 buah rekamannya.

11. Seni lukis, seni motif, seni batik, seni kaligrafi, logo dan gambar : masingmasing 10 lembar berupa foto.

12. Arsitektur: 1 buah gambar arsitektur.

13. Peta : 1 buah.

14. Fotografi : 10 lembar.

15. Sinematografi : 2 buah rekamannya.

16. Terjemahan : 2 buah naskah yang disertai izin dari pemegang Hak Cipta.

17. Tafsir, saduran dan bunga rampai 2 buah naskah.

\section{Penelitian Relevan sebelumnya}

a) Reza Aditya Ramadhan, 2020, Penelitian ini berjudul Perlindungan Warisan Budaya Seni Tari Melinting Masyarakat Adat Lampung Dalam Perspektif Sistem Hukum Kekayaan Intelektual ${ }^{31}$

Permasalahan dalam jurnal ini adalah Bagaimanakah perlindungan hukum kekayaan intelektual terhadap Ekspresi Budaya Tradisional? Dan bagaimanakah peran pemerintah provinsi Lampung dalam melindungi kekayaan intelektual terhadap hak komunal tari melinting masyarakat adat provinsi lampung?

b) Amalia Resti Faozi, 2018, Penelitian ini berjudul Perlindungan Hukum Terhadap Karya Cipta Ekspresi Budaya Tradisional di bidang Seni Tari ${ }^{32}$.

Permasalahan yang dibahas dalam jurnal ini adalah tentang perlindungan hukum terhadap ekspresi budaya tradisional pada seni tari dan model perlindungan hukum terhadap ekspresi budaya tradisional pada seni tari.

31 Ramadhan, R. A. (2020), Perlindungan Warisan Budaya Seni Tari Melinting Masyarakat Adat Lampung Dalam Perspektif Sistem Hukum Kekayaan Intelektual, Jurnal Fakultas Hukum Unila, 1 (1), h. 21.

32 Faozi, A. R. (2018). Perlindungan Hukum Terhadap Karya Cipta Ekspresi Budaya Tradisional Di Bidang Seni Tari. Skripsi. Universitas Muhammadiyah, h. 5 
c) Emma Valentina Teresha Senewe, 2015, penelitian ini berjudul Efektivitas Pengaturan Hukum Hak Cipta Dalam Melindungi Karya Seni Tradisional Daerah.

Permasalahan yang dibahas dalam jurnal ini adalah tentang pengaturan hukum hak cipta atas karya seni tradisional daerah belum efektif dan upaya pemerintah Indonesia dalam melindungi karya tradisional daerah tersebut ${ }^{33}$.

Berdasarkan penelitian relevan sebelumnya maka penelitian ini merupakan penelitian yang masih orsinil/baru karena belum ada yang membahas dengan alasan: 1) Penelitian yang telah ada tidak membahas secara komperehensif mengenai karya cipta tari Jaipongan di Jawa Barat. 2) penelitian yang sebelumnya terdapat perbedaan yang signifikan dimana seni tari yang dibahas adalah seni tari daerah Lampung atau daerah lainnya bukan daerah Jawa Barat dan tidak menjelaskan syarat-syarat pencatatan terkait karya cipta tari Jaipongan

\section{P E N U T U P}

Perlindungan Hukum terhadap karya cipta Tari Jaipongan di Jawa Barat masih sebatas pengaturan yang tercantum dalam Undang-Undang Nomor 28 Tahun 2014 tentang Hak Cipta, sehingga perlindungan terhadap karya cipta tari khususnya tari Jaipongan dirasakan belum menyentuh pada lingkup seni tari khususnya seni tari Jaipongan, khususnya terkait hak ekonomi yang tidak dapat berjalan semestinya yaitu pendapatan atas karya ciptanya dalam bentuk royalty, hal ini tentunya pengaturan tentang hak cipta tidak memiliki kepastian hukum yang diharapkan dan persyaratan pencatatan terkait karya cipta seni tari Jaipongan masih belum memiliki konsep atau persyaratan dalam prosedur pencatatan tersebut khususnya terkait ragam tari yang dapat dicatatkan di Ditjen Kekayaan Intelektual.

Oleh karena itu untuk memperoleh kepastian hukum terkait hak ekonomi yang diperoleh atas karya ciptanya dalam bentuk royalty, maka alangkah baiknya membentuk Lembaga manajemen Kolektif khusus seni tari dan seyogyanya Ditjen Kekayaan Intelektual membuat prosedur/ persyaratan terkait ciptaan yang dapat dicatatkan mengingatkan banyak ragam tari dalam karya cipta seni tari Jaipongan yang harus diperhatikan sehingga tidak menimbulkan kerancuan, apabila hal tersebut terealisasi tentunya menjadi penyemangat bagi para seniman tari khususnya seni tari Jaipongan di wilayah Jawa Barat untuk terus berkarya demi kelangsungan budaya Indonesia dan kelangsungan hidup bagi pencipta/seniman tari melalui peningkatan kesejahteraan ekonomi

\section{DAFTAR PUSTAKA}

\section{Jurnal}

[1] Alfons, M. (2019). Kepastian Hukum perolehan Hak Atas Kekayaan Intelektual, Jatiswara, 31 (2) h 303-317.

[2] Jumantri, M. C \& Nugraheni, T. (2020) Pengkajian Gaya Busana Tari Jaipongan Karya Sang Maestro. Gondang, 4 (1)

[3] Khotimah, V. (2018). Keabsahan Kepemilikan Hak Cipta Koreografi di Lingkungan Dosen Institut Seni Indonesia Yogyakarta. Jipro, 1 (1).

[4] Khutniah, N. \& Iryanti, V. E. (2012). Upaya Mempertahankan Eksistensi Tari Kridha

33 Senewe, E. V. T. (2015). Efektivitas Pengaturan Hukum Hak Cipta Dalam Melindungi Karya Seni Tradisional Daerah, LPPM Bidang EkoSosBudKum. 2 (2), h. 12 
Jati di Sanggar Hayu Budaya Keluarahan Pengkol Jepara. Jurnal seni tari Unnes, 1 (1).

[5] Labetubun, Muchtar Anshary Hamid. (2018). Aspek Hukum Hak Cipta Terhadap Buku Elektronik (E-Book) Sebagai Karya Kekayaan Intelektual, SASI 24 (2): 138-149.

[6] Mahardhita, Y. \& Sukro, A. Y. (2018). Perlindungan hukum hak kekayaan intelektual melalui mekanisme "cross border measure. Qistie 11 (1).

[7] Marlianti, M., Saidi, A. I., Destiarmand, A. H. (2017). Pergeseran Bentuk Siluet Kostum tari Jaipongan tahun 1980-2010. Panggung, 27 (1).

[8] Napitupulu, D. P. T. \& Muaz Zul. (2013). Perlindungan Hak Cipta Kesenian Daerah Tari Tor-Tor dan Gondang Sembilan. Mercatoria, 6 (1).

[9] Nuriawati, R. \& Nalan, A. S. (2018). Kreativitas Gondo Dalam Tari Jaipongan. Makalangan, 5 (2).

[10] Raharjo, R. S. (2018). Perlindungan Hukum terhadap Pencipta atas Pencatatan Suatu Ciptaan yang Sama. Lentera Hukum, 5 (3).

[11] Ramadhan, R. A. (2020). Perlindungan Warisan Budaya Seni Tari Melinting Masyarakat Adat Lampung Dalam Perspektif Sistem Hukum Kekayaan Intelektual. Jurnal Fak Hukum Unila, 1 (1)

[12] Senewe, E. V. T. (2015). Efektivitas Pengaturan Hukum Hak Cipta Dalam Melindungi Karya. LPPM Bidang EkoSosBudKum, 2 (2)

\section{Buku}

[13]Badan Penelitian dan Pemnembangan HAM Kemhan RI. (2013) Perlindungan Kekayaan Intelektual atas Pengetahuan Tradisional dan ekspresi budaya Tradisional masyarakat adat. Bandung: Alumni

[14] Nainggolan, B. (2011). Pemberdayaan Hukum Hak Cipta lagu dan music melalui fungsi Lembaga manajemen Kolektif. Bandung: Alumni.

[15] Rahmadi. (2010). Hukum Hak Atas Kekayaan Intelektual. Bandung: Alumni.

[16][18]Ronny Hanitijo Soemitro, (2014) Metodologi Penelitian Hukum dan Jurimentri. Jakarta: Ghalia Indonesia.

[17] Soekanto, S. (2014) Pengantar Penelitian Hukum. Jakarta: Universitas Indonesia-Press. [18] Soelistyo, H. (2011). Hak Cipta tanpa Hak Moral. Jakarta: Rajawali.

[19] Sudikno. (2010). Perkembangan Teori dalam Ilmu Hukum. Jakarta: Radja Grafindo

\section{Skripsi, Tesis, Disertasi dan Lain-Lain}

[20]Faozi, A. R. (2018). Perlindungan Hukum Terhadap Karya Cipta Ekspresi Budaya Tradisional Di Bidang Seni Tari, Skripsi. Universitas Muhammadiyah.

[21] Juwita. (2016). Perlindungan Hukum terhadap Karya cipta tari di Indonesia, Desertasi, Universitas Hasanuddin.

[22] Rahardja, D. M. (2015). Perlindungan Hukum Terhadap Pencipta Lagu Yang Belum Di Daftarkan Ke Direktorat Jendral Hak Kekayaan Intelektual, Skripsi. Universitas Brawijaya.

\section{Online/World Wide Web}

[23] Am Badar \& Partners (2020) https://ambadar.co.id/news/pendaftaran-hak-cipta-diindonesia/ 